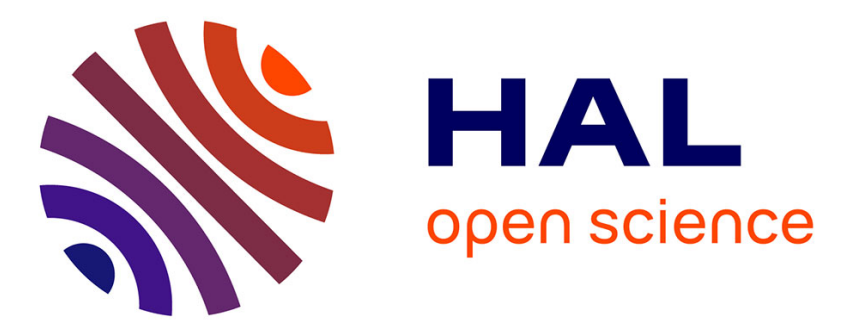

\title{
The procyclicality of loan loss provisions in Islamic banks: Do managerial discretions matter?
}

\author{
Wahyoe Soedarmono, Sigid Eko Pramono, Amine Tarazi
}

\section{To cite this version:}

Wahyoe Soedarmono, Sigid Eko Pramono, Amine Tarazi. The procyclicality of loan loss provisions in Islamic banks: Do managerial discretions matter?. 2016. hal-01281151

\section{HAL Id: hal-01281151 \\ https://hal-unilim.archives-ouvertes.fr/hal-01281151}

Preprint submitted on 1 Mar 2016

HAL is a multi-disciplinary open access archive for the deposit and dissemination of scientific research documents, whether they are published or not. The documents may come from teaching and research institutions in France or abroad, or from public or private research centers.
L'archive ouverte pluridisciplinaire HAL, est destinée au dépôt et à la diffusion de documents scientifiques de niveau recherche, publiés ou non, émanant des établissements d'enseignement et de recherche français ou étrangers, des laboratoires publics ou privés. 


\title{
The procyclicality of loan loss provisions in Islamic banks: Do managerial discretions matter?
}

\author{
Wahyoe Soedarmono* ${ }^{1}$, Sigid Eko Pramono**, Amine Tarazi*** \\ *Sampoerna University/ Sampoerna School of Business, Jakarta, Indonesia \\ ** Bank Indonesia \\ ***Universite de Limoges, LAPE, France
}

\begin{abstract}
This paper is the first to examine whether the loan loss provisioning behavior of Islamic banks is procyclical. From a dynamic panel data methodology, the empirical results show that loan loss provisioning in Islamic banks is indeed procyclical, as higher economic growth leads to a decline in loan loss provisions. A closer investigation is also conducted to examine whether capital management, income smoothing, or signaling behavior can alter the procyclicality of loan loss provisions. Specifically, our results document that only capital management behavior can overcome the procyclicality of loan loss provisions. This paper therefore advocates the importance of strengthening discretionary behavior in Islamic banks in terms of capital management using loan loss provisions, particularly during economic boom.
\end{abstract}

Keywords: Islamic banks, loan loss provisions, procyclicality

JEL Classification: G15, G21, M41

\footnotetext{
${ }^{1}$ Corresponding author. Tel.:+62 21794 2340. Fax: +62 217942330.

Email: wahyoe.soedarmono@usbi.ac.id or wahyoe.soedarmono@sampoernauniversity.ac.id (W.Soedarmono), sigidpram@bi.go.id (S.E. Pramono), amine.tarazi@unilim.fr (A. Tarazi)
} 


\section{Introduction}

In the aftermath of the 2008 global financial crisis, the importance of strengthening prudential regulation in banking has acquired greater attention from academics and policy makers. This is because banks tend to behave imprudently during economic boom by lowering credit standards to boost loans, but strengthening credit standards during economic downturn when higher amount of loans is necessary to help economic recovery. Such bank behavior is often referred to as the procyclicality of bank credit risk management (Altman, 2005).

Prior literature on the procyclicality of bank credit management has been devoted to analyze the implication of loan loss provisioning system. Arpa et al. (2001) show that bank loan loss provisions are procyclical with business cycle in the case of Austrian commercial banks. Cavallo and Majnoni (2002) also show that higher economic growth is associated with a decline in loan loss provisions in banking. Laeven and Majnoni (2003) subsequently report that loan loss provisions indeed decreases following higher earnings and loan activities due to economic boom.

For commercial banks operating in OECD countries, loan loss provisioning system is also procyclical as in Bikker and Metzemakers (2005). Bouvatier and Lepetit (2008) find the similar results for European banks, but they consider the impact of non-discretionary and discretionary provisions on loan growth ${ }^{2}$. Specifically, only discretionary provisions have a procyclical impact. Bouvatier and Lepetit (2012) extend their prior work by including bank sample from developing countries. They show that non-discretionary provisions still have a procyclical impact regardless of whether or not income smoothing is conducted. Their results also show that the procyclicality of loan loss provisions is more pronounced in developing countries.

Another strand of literature divides loan loss provisions into two components: general and specific provisions (Cortavaria et al., 2000). While general provisions aim to mitigate unexpected credit risk in the future, specific provisions are used to cover expected credit risk. Accordingly, general provisions can be considered a forwardlooking component, while specific provisions are a backward-looking component. Because general provisions is a forward-looking component, whether or not general

\footnotetext{
${ }^{2}$ Non-discretionary provisions are related to specific provisions that aim to cover expected credit risk, while discretionary provisions are related to general provisions that are also affected by managerial objective such as capital management, income smoothing or signaling.
} 
provisions change is therefore affected by banks' managerial discetionary behavior (Whalen, 1994; Beaver and Engel, 1996). Prior litetrature indicates that the discretionary behavior of bank managers in determining the amount of loan loss provisions consists of capital management, income smoothing and signaling behavior (Bouvatier and Lepetit, 2008; Ahmed et al., 1999; Lobo and Yang, 2001). This means that banks may increase loan loss provisions provisions to exercise different set of strategies; whether to enhance capital management, smooth earnings, signal its strength to market, or combination of these strategies.

In order to deal with the procyclicality of loan loss provisions, Fernandez de Lis et al. (2001) shed light on the importance of dynamic provisioning system, especially when discretionary provisions cannot offset the procyclicality of nondiscretionary provisions. In this regard, the dynamic provisioning system requires additional type of provisions, which is statistical provisions. The creation of statistical provisions will smooth total provisions (general, specific and statistical provisions) during economic downturn, because banks already create statistical provisions as buffer during economic boom. This implies that loans disbursement during economic downturn can be maintained and hence, supporting economic recovery processes.

While the implementation of dynamic provisioning system for conventional banks has been widely assessed, there is no prior study that examines the similar issue for Islamic banks. For countries with dual banking system, understanding whether the current loan loss provisioning system in Islamic banks is procyclical provides important insights on the potential implication of dynamic provisioning system for Islamic banks. To the best of our knowledge, this paper is therefore the first attempt to investigate the procyclicality issues of loan loss provisions for Islamic banks. Our contribution in the present paper is twofold. First, we test how economic growth affects loan loss provisions in Islamic banks. Hence, we may characterize the presence of procyclicality, if higher economic growth is associated with lower loan loss provisions. Second, we augment the analysis by examining whether the procyclicality of loan loss provisions, if any, is conditional on banks' managerial discretionary behavior, which is related to capital management, income smoothing and signaling. As such, we may highlight whether or not the discretionary behavior of Islamic banks is sufficient to offset the procyclicality of loan loss provisions. Eventually, this paper may provide policy implications whether the implementation of 
dynamic provisioning system is necessary for Islamic banks with different accounting standards compared to conventional banks.

As a matter of fact, the AAOIFI (Accounting and Auditing Organization for Islamic Financial Institutions) - which has been established to harmonize regulatory frameworks that involve Islamic principles (Grais and Pellegrini, 2006) - also advocates the importance of implementing dynamic provisioning system for Islamic banks to cope with unexpected risks due to the difference in accounting treatment (Quttainah et al., 2011). Unexpected risks of Islamic banks may come from PLS (profit-loss sharing) contracts that basically have two types of investment account: Restricted Investment Account Holder (RIAH) and Unrestricted Investment Account Holder (UIAH). These contracts can be reported differently in bank income statement. Karim (2001) points out that some Islamic banks treat RIAH as equity or liability, while others consider it as off-balance sheet item.

Ultimately, since Islamic banks' activities are based on PLS contracts, their credit risk management is also different than conventional banks. Understanding the procyclicality of loan loss provisions in Islamic banks is therefore crucial, as Islamic banks grow rapidly across countries from time to time. In 2016, Islamic banks around the world is predicted to grow by 90 percent with the total assets, reaching more than USD 1.8 trillion compared to only USD 939 billion in 2010 (Cevik and Charap, 2011). As the presence of Islamic banks becomes substantial, its role in economic development will be more pronounced than before. In this respect, addressing the procyclicality issues of loan loss provisions in Islamic banks should be more of a concern, particularly during economic downturn.

The remainder of this paper is organized as follows. Section 2 presents our data and hypotheses development. Section 3 presents our methodology and variables. Section 4 describes empirical results, while Section 5 concludes the paper.

\section{Data and hypothesis development}

\subsection{Data sources}

For the purpose of this study, we retrieve a sample of 146 Islamic banks around the world from 1997 to 2012 covered by BankScope Fitch IBCA. Specifically, we retrieve balance sheet and income statement information of Islamic banks from the following countries: United Arab Emirates (10), Bangladesh (2), Bahrain (19), Brunei Darussalam (1), Egypt (2), UK (5), Gambia (1), Indonesia (3), Iraq (6), Iran (16), 
Jordan (3), Kuwait (9), Cayman Islands (1), Lebanon (3), Mauritania (2), Maldives (1), Malaysia (17), Philippines (1), Pakistan (9), Palestinian Territory (2), Qatar (4), Russia (1), Saudi Arabia (4), Sudan (12), Singapore (1), Syiria (2), Tunisia (1), Turkey (4), and Yemen (4) $)^{3}$. We also include macroeconomic data such as real gross domestic product obtained from the World Bank.

\subsection{Hypothesis development}

The objective of this study is twofold. First, we aim to test whether the procyclicality of loan loss provisions occurs by running regressions of loan loss provisions on economic growth as explanatory variable of interest. Second, we test whether the procyclicality of loan loss provisions is conditional on Islamic banks' managerial discretionary behavior comprising capital management, income smoothing and signaling.

For such purposes, we specify Hypothesis 1 and Hypothesis 2 to tackle the first and second objective, respectively:

Hypothesis 1: Islamic banks build up higher loan loss provisions following economic boom

Hypothesis 2 : Islamic banks' behavior in building up loan loss provisions in response to economic growth depends on the degree of banks' managerial discretionary behavior related to capital management, income smoothing or signaling.

Previous studies indeed document that bank capital management may affect loan loss provisioning behavior of banks (Bouvatier and Lepetit, 2008; Parker and Zhu, 2012). Specifically, Bouvatier and Lepetit (2008) report that banks with poor capitalization are less inclined to build up loan loss provisions, while Parker and Zhu (2012) show that income smoothing strategies tend to be adopted in well-capitalized banks in Japan and poorly-capitalized banks in India. In this context, the role of bank capital management and income smoothing can not be separated in examining the issues of procyclicality in banking. Phrased differently, aside from capital

\footnotetext{
${ }^{3}$ The number of banks are in parentheses.
} 
management, income smoothing using loan loss provisions should also be examined whether it affects the procyclicality of loan loss provisions. In parallel, signaling strategies using loan loss provisions are also somehow related to income smoothing strategies, as banks may signal its strength when they may generate higher profits and, thus, loan loss provisions. For such reasons, Hypothesis 2 considers not only the discretionary behavior of Islamic related capital management, but also income smoothing and signaling to examine whether the impact of economic growth on loan loss provisions depends on managerial discretions.

\section{Methodology and variables}

The methodology used in this paper comprises two stages. In the first stage, we test the occurrence of procyclical effect of loan loss provisions as stated in Hypothesis 1, while the second stage is to examine whether capital management, income smoothing or signaling using loan loss provisions during economic boom can offset the procyclicality of loan loss provisions as shown in Hypothesis 2.

Hypothesis 1 can be tested using the following equations in which we introduce the one-year-lagged value of dependent variable as control variable.

$$
\begin{aligned}
& \operatorname{LLPTA}_{i, t}=\alpha_{0} \text { LLPTA }_{i, t-1}+\alpha_{1} \text { LTA }_{i, t}+\alpha_{2} N P L_{i, t}+\alpha_{3} G R O W T H+\varepsilon_{i, t} \\
& \text { LLRTA }_{i, t}=\alpha_{0} \text { LLRTA }_{i, t-1}+\alpha_{1} \text { LTA }_{i, t}+\alpha_{2} N P L_{i, t}+\alpha_{3} G R O W T H+\varepsilon_{i, t}
\end{aligned}
$$

In Eq. (1a) and Eq. (1b), we merely focus on the determinants of loan loss provisions that may reflect non-discretionary behavior of bank managers, because the procyclicality of loan loss provisions is mostly related to non-discretionary component of loan loss provisions (Bouvatier and Lepetit, 2008 \& 2012). On the other hand, adding more variables reflecting discretionary component of loan loss provisions into Eq. (1a) and Eq. (1b) will make the degree of freedom becomes smaller when we have only limited number of Islamic banks available in our sample.

From Eq. (1a), LLPTA is the ratio of loan loss provisions to total assets. For robustness consideration, we also use the ratio of loan loss reserves to total assets (LLRTA) as depenent variable in Eq. (1b). LTA is the ratio of total loans to total assets, while NPL is the ratio of non-performing loans to total loans and GROWTH is the real economic growth rate at the country level. 
In the next turn, Hypothesis 2 can be tested using the following equations in which we add interaction terms between economic growth and three discretionary purposes of Islamic bank managers using loan loss provisions.

$$
\begin{aligned}
& \operatorname{LLPTA}_{i, t}=\alpha_{0} \mathrm{LLPTA}_{i, t-1}+\alpha_{1} \mathrm{LTA}_{i, t}+\alpha_{2} N P L_{i, t}+\alpha_{3} \text { GROWTH }+ \\
& +\alpha_{4} C A P+\alpha_{5} C A P * G R O W T H+\varepsilon_{i, t} \\
& \operatorname{LLRTA}_{i, t}=\alpha_{0} \mathrm{LLPTA}_{i, t-1}+\alpha_{1} \mathrm{LTA}_{i, t}+\alpha_{2} N P L_{i, t}+\alpha_{3} \text { GROWTH }+ \\
& +\alpha_{4} C A P+\alpha_{5} C A P * G R O W T H+\varepsilon_{i, t} \\
& \operatorname{LLPTA}_{i, t}=\alpha_{0} \text { LLPTA }_{i, t-1}+\alpha_{1} \text { LTA }_{i, t}+\alpha_{2} \mathrm{NPL}_{i, t}+\alpha_{3} \text { GROWTH }+ \\
& +\alpha_{4} E B T P+\alpha_{5} E B T P * G R O W T H+\varepsilon_{i, t} \\
& \operatorname{LLRTA}_{i, t}=\alpha_{0} \text { LLPTA }_{i, t-1}+\alpha_{1} L_{T A}+\alpha_{i, t} N P L_{i, t}+\alpha_{3} G R O W T H+ \\
& +\alpha_{4} E B T P+\alpha_{5} E B T P * G R O W T H+\varepsilon_{i, t} \\
& \operatorname{LLPTA}_{i, t}=\alpha_{0} \mathrm{LLPTA}_{i, t-1}+\alpha_{1} \mathrm{LTA}_{i, t}+\alpha_{2} N P L_{i, t}+\alpha_{3} \text { GROWTH }+ \\
& +\alpha_{4} S I G N+\alpha_{5} S I G N * G R O W T H+\varepsilon_{i, t} \\
& \operatorname{LLRTA}_{i, t}=\alpha_{0} \mathrm{LLPTA}_{i, t-1}+\alpha_{1} \mathrm{LTA}_{i, t}+\alpha_{2} N P L_{i, t}+\alpha_{3} \text { GROWTH }+ \\
& +\alpha_{4} S I G N+\alpha_{5} S I G N * G R O W T H+\varepsilon_{i, t}
\end{aligned}
$$

Eq. (2a) and Eq. (2b) contain the interaction term between capitalization and economic growth $\left(C A P^{*} G R O W T H\right)$ in order to examine the role of capital management in affecting the impact of economic growth on loan loss provisions. CAP is defined as the ratio of total equity to total assets. Meanwhile, the role of income smoothing in affecting the procyclicality of loan loss provisions due to economic growth is estimated using Eq. (2c) and Eq. (2d) by incorporating the interaction term between income smoothing and economic growth $\left(E B T P^{*} G R O W T H\right)$. EBTP is the income smoothing variable defined as the ratio of earning before tax and provisions divided by total assets. Finally, Eq. (2e) and Eq. (2f) contain the interaction term between signaling and economic growth $(S I G N * G R O W T H)$ which aims to investigate how signaling behavior affects the link between economic growth and loan loss provisions. SIGN captures signaling behavior, which is measured by:

$$
S I G N_{i, t}=\frac{E R_{i, t+1}-E R_{i, t}}{0.5\left(T A_{i, t+1}+T A_{i, t}\right)}
$$


$E R$ is defined as earnings before tax and loan loss provisions, while $T A$ is total assets.

Overall, we estimate Eq. (1a) to Eq. (2f) using a dynamic panel data methodology for several reasons. First, the current loan loss provisioning behavior might be affected by the last year's provisioning behavior due to managerial learning and, thus, loan loss provisions are dynamic rather than static variable. Therefore, the use of dynamic panel data methodology is proper to control for dynamic movements of loan loss provisions. Second, loan loss provisions can be affected by explanatory variables introduced from Eq. (1a) to Eq. (2f), but those explanatory variables can also be affected by loan loss provisions. If this is the case, reverse causality problems might be an important drawback that acquires particular attention. The use of dynamic panel data methodology is also relevant, because it can avoid reverse causality problems between loan loss provisions and their determinants.

In terms of econometric procedure, we follow Blundell and Bond (1998) to estimate dynamic panel data models as shown in Eq. (1a) - Eq.(2f). This method is referred to as the two-step system GMM estimation or the system GMM. The system GMM is shown to be more efficient than the standard GMM (Baltagi, 2005). We consider orthogonal transformations of instruments to control for possible crosssectional fixed effects, while we also include Windmeijer's (2005) finite sample correction to ensure for the validity of the system GMM. Finally, the system GMM is valid when both the AR(2) and Hansen-J test are not significant, indicating that there is no second order autocorrelation among errors and overidentifying restrictions are valid, respectively.

\section{Empirical results}

\subsection{Results}

In Table 1, we present descriptive statistics of variables used in this study. No potential outliers can be detected, as the values of each variable seem economically plausible. We also eliminate all zero values in each variable to ensure that unavailable data is not treated as zero in our model estimations. Meanwhile, Table 2 presents the correlation structure of all variables. We can notice that all independent variables presented from Eq. (1a) to Eq. (2f) are not highly correlated and hence, potential multicollinearity problems are less likely to occur.

[Insert Table 1 and Table 2 here] 
In Table 3, we document that Islamic banks use loan loss provisions for nondiscretionary purposes in which higher loan-to-asset ratio (LTA) and non-performing loans $(N P L)$ are associated with higher loan loss provisions. These results are consistent with prior literature on the procyclicality of loan loss provisions in conventional banks (e.g. Bouvatier and Lepetit, 2008 \& 2012; Bikker and Metzemakers, 2005). More importantly, loan loss provisions of Islamic banks are procyclical, as higher economic growth deteriorates loan loss provisions. Hypothesis 1 is therefore not rejected. Our dynamic panel data models to test Hypothesis 1 are also valid, because both the $\operatorname{AR}(2)$ and Hansen-J test are not significant. Such procyclical behavior of Islamic banks in building up loan loss provisions is indeed consistent with the results obtained for conventional banks as in prior literature presented earlier.

\section{[Insert Table 3 here]}

Furthermore, we present our empirical results to test Hypothesis 2 in Table 4. Model 1 is addressed to test whether capital management using loan loss provisions affects the procyclicality of loan loss provisions, while Model 2 and Model 3 are to test the impact of income smoothing and signaling behavior using loan loss provisions on the procyclicality of loan loss provisions, respectively.

\section{[Insert Table 4 here]}

From Table 4, it is shown that higher loan loss provisions are still affected by the loan-to-assets ratio ( $L T A)$ and non-performing loans $(N P L)$. In this context, the use of loan loss provisions for non-discetionary purposes as discussed earlier is not altered. Meanwhile, higher economic growth $(G R O W T H)$ still has a negative impact on loan loss provisions measured by either LLPTA or LLRTA. However, we find that only bank discretionary behavior related to capital management alters the procyclicality of loan loss provisions, as shown by the positive coefficients of interaction variable between capitalization $(C A P)$ and economic growth (GROWTH) in Model 1 (Table 4). The positive coefficients of $C A P^{*} G R O W T H$ is also higher than the negative coefficients of GROWTH. 
For instance, if LLPTA is used as dependent variable, the negative impact of GROWTH on loan loss provisions indicating the procyclicality of loan loss provisions occurs when $C A P$ is less than 24 percent. In other words, this may also indicate that the countercyclical effect of loan loss provisions is apparent if the equity-to-assets ratio exceeds 24 percent. The identical results occur when we use LLRTA as dependent variable, where the cut-off point of CAP is 3 percent in order to enable loan loss reserves become countercyclical.

All in all, loan loss provisions in Islamic banks with higher capitalization are countercyclical, because loan loss provisions increase in response to stronger economic growth. Islamic banks with higher capitalization are indeed more prudent by building up higher loan loss provisions during economic boom, which in turn enables them to decrease loan loss provisions in bad times. Consequently, banks with higher capitalization can boost loans disbursement during economic downturn. We therefore highlight that Islamic banks with higher capitalization may contribute well to economic recovery. Finally, our models estimated in Table 4 are valid, because the $\mathrm{AR}(2)$ test and the Hansen-J test are not significant at least at the 5 percent level.

\subsection{Robustness checks}

In order to ensure the robustness of our empirical models, we modify the specification of our dynamic panel data models. Specifically, we follow Bouvatier and Lepetit (2008) by considering first-difference transformation instead of orthogonal deviation transformation of instruments. Table 5 and Table 6 present our results using this new specification. On the whole, the empirical results discussed earlier are not altered. All dynamic panel data models using first difference transformation of instruments are still valid, because the AR(2) test and the Hansen-J test are not rejected.

[Insert Table 5 and Table 6 here]

\section{Conclusion}

This paper is the first to examine whether the loan loss provisioning of Islamic banks is procyclical over business cycle. Our empirical results are supportive of the notion that loan loss provisions in Islamic banks are generally procyclical, because loan loss provisions decreases due to stronger economic growth. In other words, 
Islamic banks' provisioning behavior might deepen economic recessions, as loan loss provisions increases in response to a decline in economic growth.

However, a closer investigation reveals that the procyclicality of loan loss provisions can be offset by discretionary behavior of bank managers, particularly related to capital management behavior. In this sense, enhancing capital management using loan loss provisions as a discretionary behavior of Islamic bank managers during economic boom is more than sufficient to ensure that loan loss provisions increase in good times, but decrease in bad times. Accordingly, the use of dynamic provisioning system as recommended by the AAOIFI is not crucial for Islamic banks, because relying on the discretionary behavior of Islamic bank managers related to capital management using loan loss provisions can already offset the procyclicality of loan loss provisions.

\section{References}

Ahmed, A.S. et al. (1999), "Bank loan loss provisions: A reexamination of capital management, earnings management and signaling effects", Journal of Accounting and Economics, 28, 1-25

Altman, E.I. et al. (2005), "The link between default and recovery rates: Theory, empirical evidence, and implications", Journal of Business, 78, 2203-2228.

Altunbas, Y. et al.(2009), "Securitisation and the bank lending channel", European Economic Review, 53, 996-1009.

Archer, S. and R.A.A. Karim (2006), "On capital structure, risk sharing and capital adequacy in Islamic banks", International Journal of Theoretical and Applied Finance, 9 (3), 269-80.

Arpa, M. et al. (2001), “The influence of macroeconomic developments on Austrian banks: implications for banking supervision”, BIS Papers, 1, 91-116.

Baltagi, B.H. (2005). Econometric Analysis of Panel Data, third ed. John Wiley \& Sons Ltd., Chichester. 
Beaver, W.H. and E. Engel (1996), "Discretionary behavior with respect to allowances for loan losses and the behavior of security prices", Journal of Accounting and Economics, 22, 177-206.

Bikker, J.A. and P. Metzemakers (2005), "Bank provisioning behavior and procyclicality”, Journal of International Financial Markets, Institutions and Money, $15,141-157$.

Blundell, R., \& Bond, S. (1998) "Initial conditions and moment restrictions in dynamic panel data models" Journal of Econometrics, 87, 115-143.

Bouvatier, V. and L. Lepetit (2012), "Effects of loan loss provisions on growth in bank lending: Some international comparisons", International Economics, 132, 91116.

Bouvatier, V. and L. Lepetit (2008), “Banks' procyclical behavior: does provisioning matter?", Journal of International Financial Markets, Institutions and Money, 18, 513-526.

Cavallo, M. and G. Majnoni (2002), "Do banks provision for bad loans in good times? Empirical evidence and policy implications" In: Levich, R., Majnoni, G., Reinhart, C. (Eds.), Ratings, Rating Agencies and the Global Financial System. Kluwer Academic Publishers, Boston, Dordrecht, London.

Cevik, S. and J. Charap (2011), "The Behavior of Conventional and Islamic Bank Deposit Returns in Malaysia and Turkey", IMF Working Paper, 11/156.

Cortavarria, L. et al. (2000), "Loan review, provisioning, and macroeconomic linkages", IMF Working Papers, 00/195.

Errico, L. and M. Farahbaksh (1998), "Islamic Banking: Issues in Prudential Regulations and Supervision”, IMF Working Paper, 98/30. 
Fernandez de Lis, S. et al. (2001), "Credit growth, problem loans and credit risk provisioning in Spain", BIS Papers, 1, 331-353.

Grais, W. and M. Pellegrini (2006), “Corporate governance and Shari'ah compliance in institutions offering Islamic financial services", World Bank Policy Research Working Paper.

Karim, R.A.A. (2001), “International accounting harmonization, banking regulation, and Islamic banks", The International Journal of Accounting, 36 (2001), 169-193.

Kashyap, A.K. and J.C. Stein (2000), "What do a million observation on banks say about the transmission of monetary policy?", American Economic Review, 407-428.

Laeven, L. and G. Majnoni (2003), "Loan loss provisioning and economic slowdowns: too much, too late?", Journal of Financial Intermediation, 12, 178-197.

Lobo, G.L. and D.H. Yang (2001), "Bank managers' heterogeneous decisions on discretionary loan loss provisions", Review of Quantitative Finance and Accounting, $16,223-250$.

Pain, D. (2003), "The provisioning experience of the mayor UK banks: a small panel investigation”, BOE Working Paper, 177.

Parker, F. and H. Zhu (2012), "Loan loss provisioning practices of Asian banks", BIS Working Paper, 375.

Quttainah, M.A. et al. (2011), "Do Islamic Banks Employ Less Earnings Management?”, Paper on Economic Research Forum, Oct, 2011.

Whalen, J.M. (1994), "The nature of information in commercial bank loan loss disclosures", The Accounting Review, 69, 455-478.

Windmeijer, F. (2005) "A finite sample correction for the variance of linear efficient two-step GMM estimators" Journal of Econometrics, 126, 25-51. 
Table 1. Descriptive statistics

\begin{tabular}{|c|c|c|c|c|c|c|}
\hline Variable & Definition & Obs & Mean & Std. Dev. & Min & Max \\
\hline LLPTA & Ratio of loan loss provisions to total assets & 694 & 0.0075819 & 0.0151546 & -0.126497 & 0.1412412 \\
\hline LLRTA & Ratio of loan loss reserves to total assets & 702 & 0.0264963 & 0.0379222 & 0.0001125 & 0.4414414 \\
\hline$L T A$ & Ratio of total loans to total assets & 999 & 0.4747414 & 0.2548028 & 2.41E-06 & 0.9927928 \\
\hline$N P L$ & Ratio of non-performing loans to total assets & 417 & 0.0870674 & 0.1334875 & 0.0000941 & 0.831972 \\
\hline GROWTH & Real gross domestic product growth & 1684 & 0.0469603 & 0.0542033 & -0.413 & 0.465 \\
\hline$C A P$ & Ratio of total equity to total assets & 1050 & 0.2621883 & 0.2636642 & -0.5892856 & 1 \\
\hline EBTP & Ratio of earning before tax and provisions to total assets & 724 & 0.0182807 & 0.043667 & -0.4108263 & 0.2611041 \\
\hline SIGN & Signaling variable & 585 & 0.0044359 & 0.0427708 & -0.3834767 & 0.3486663 \\
\hline
\end{tabular}

Table 2. Correlation structure

\begin{tabular}{|c|c|c|c|c|c|c|c|c|}
\hline Variables & LLPTA & LLRTA & LTA & $N P L$ & GROWTH & CAP & EBTP & SIGN \\
\hline LLPTA & 1 & & & & & & & \\
\hline LLRTA & 0.2766 & 1 & & & & & & \\
\hline$L T A$ & 0.143 & 0.3512 & 1 & & & & & \\
\hline$N P L$ & 0.3699 & 0.7021 & 0.0009 & 1 & & & & \\
\hline GROWTH & -0.0648 & -0.002 & 0.0428 & -0.0077 & 1 & & & \\
\hline$C A P$ & -0.1161 & 0.1479 & 0.0044 & 0.1388 & 0.0135 & 1 & & \\
\hline EBTP & -0.1322 & 0.0619 & 0.3473 & -0.1635 & 0.1967 & -0.0158 & 1 & \\
\hline SIGN & 0.0123 & -0.004 & 0.0188 & -0.1135 & -0.0321 & -0.0018 & -0.6156 & 1 \\
\hline
\end{tabular}


Table 3. The procyclicality of loan loss provisions

\begin{tabular}{|c|c|c|}
\hline \multirow[b]{2}{*}{ Explanatory variables } & \multicolumn{2}{|c|}{ Dependent variables } \\
\hline & LLPTA & LLRTA \\
\hline $\operatorname{LLPTA}(-1)$ & $\begin{array}{l}0.6973 * * * \\
(0.144)\end{array}$ & \\
\hline $\operatorname{LLRTA}(-1)$ & & $\begin{array}{l}0.7768 * * * \\
(0.035)\end{array}$ \\
\hline$L T A$ & $\begin{array}{l}0.0042 * * * \\
(0.002)\end{array}$ & $\begin{array}{l}0.0091 * * * \\
(0.002)\end{array}$ \\
\hline$N P L$ & $\begin{array}{l}0.0130 \\
(0.022)\end{array}$ & $\begin{array}{l}0.0619 \text { *** } \\
(0.013)\end{array}$ \\
\hline GROWTH & $\begin{array}{l}-0.0245^{* *} \\
(0.009)\end{array}$ & $\begin{array}{l}-0.0500 * * * \\
(0.017)\end{array}$ \\
\hline Observations & 311 & 310 \\
\hline Number of index & 73 & 72 \\
\hline $\operatorname{AR}(2)$ test ( $p$-value) & 0.981 & 0.350 \\
\hline Hansen-J test ( $p$-value) & 0.420 & 0.126 \\
\hline
\end{tabular}

Notes: The definition of variables follows Table 1. Regressions are carried out using the system GMM following Blundell and Bond (1999) by taking orthogonal deviation of instruments into account and hence, we control for cross-sectional fixed effects. Models are valid if the AR(2) and Hansen-J test are not significant. $* * *, * *, *$ indicate significance at the 1 percent, 5 percent, and 10 percent levels, respectively. 
Table 4. Do capital management, income smoothing and signaling alter the procyclicality of loan loss provisions?

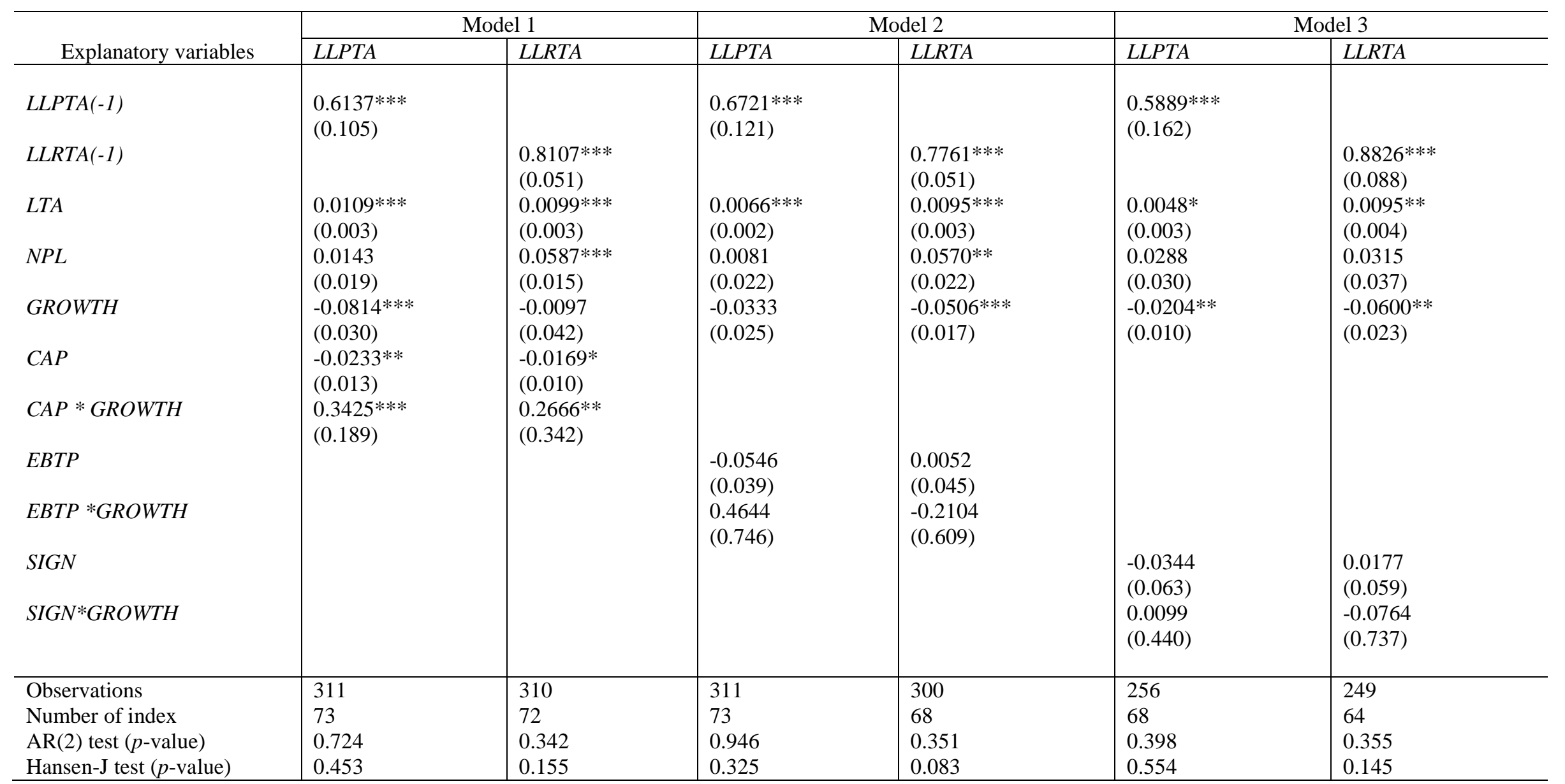

Notes: The definition of variables follows Table 1. Regressions are carried out using the system GMM following Blundell and Bond (1999) by taking orthogonal deviation of instruments into account and hence, we control for cross-sectional fixed effects. Models are valid if the AR(2) and Hansen-J test are not significant. $* * *, * *, *$ indicate significance at the 1 percent, 5 percent, and 10 percent levels, respectively. 
Table 5. The procyclicality of loan loss provisions: First-difference transformation

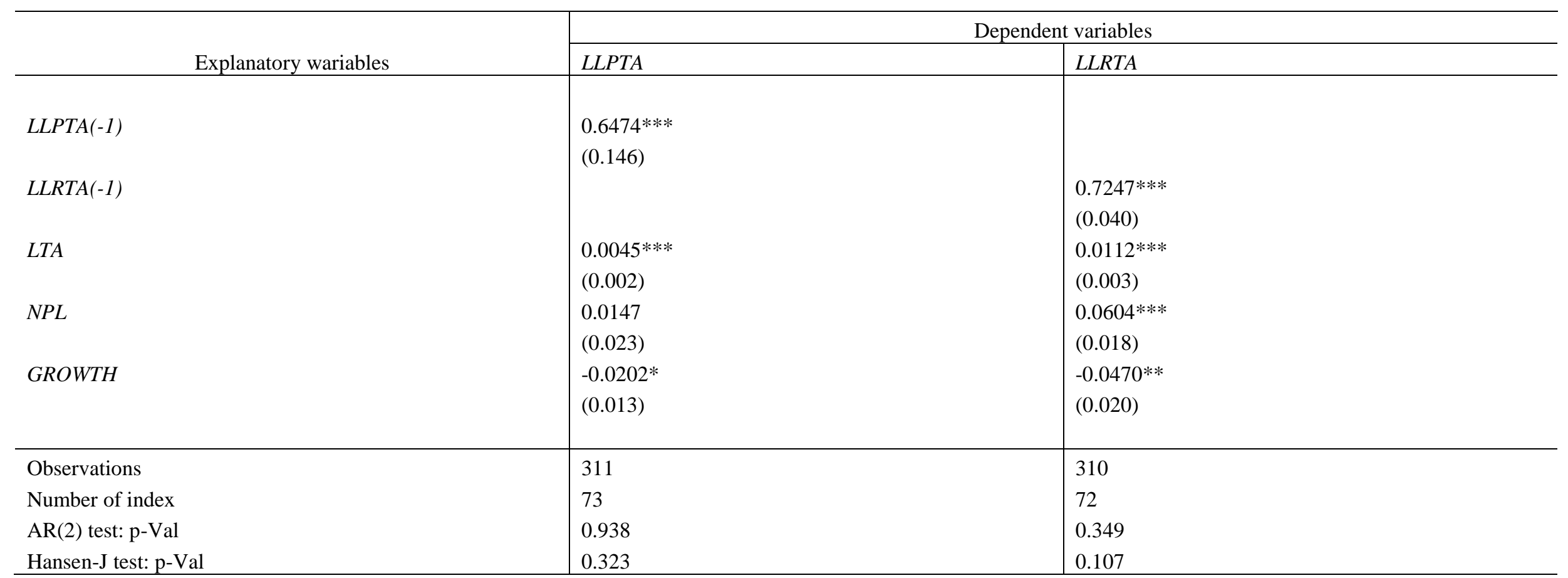

Notes: The definition of variables follows Table 1. Regressions are carried out using the system GMM following Blundell and Bond (1999) by taking firstdifference transformation of instruments into account and hence, we control for cross-sectional fixed effects. Models are valid if the AR(2) and Hansen-J test are not significant. ${ }^{* *}, * *, *$ indicate significance at the 1 percent, 5 percent, and 10 percent levels, respectively. 
Table 6. Capital management, income smoothing, signaling and the procyclicality of loan loss provision: First-difference transformation

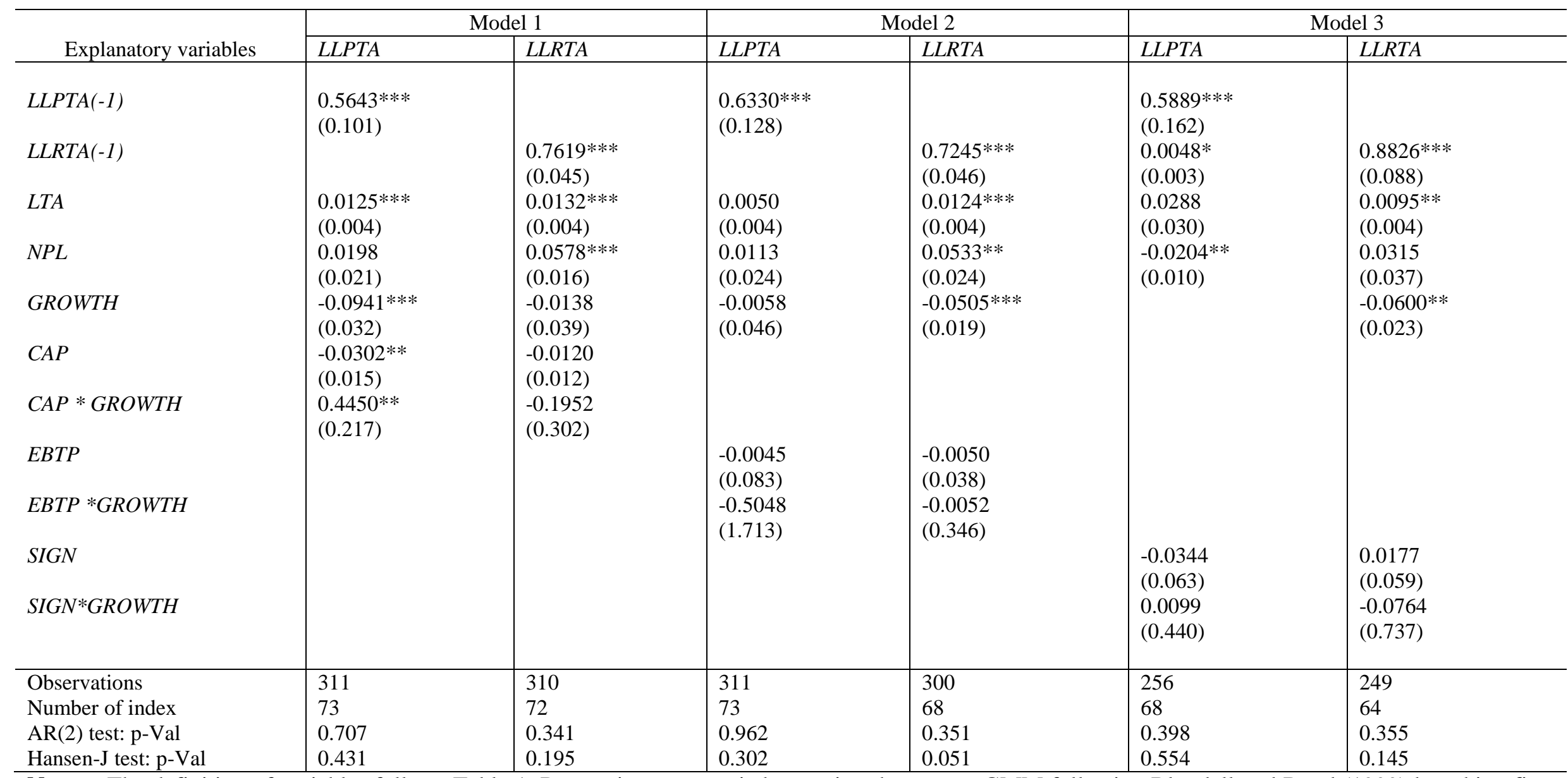

Notes: The definition of variables follows Table 1. Regressions are carried out using the system GMM following Blundell and Bond (1999) by taking firstdifference transformation of instruments into account and hence, we control for cross-sectional fixed effects. Models are valid if the AR(2) and Hansen-J test are not significant. $* * *, * * *$ indicate significance at the 1 percent, 5 percent, and 10 percent levels, respectively. 